\title{
Haryana- Heaven for Most Economical Treatment in World for Hepatitis C
}

\author{
Parveen Malhotra*, Vani Malhotra, Naveen Malhotra, Isha Pahuja, Ajay Chugh and Sunneta Chaudhary \\ Department of Medical Gastroenterology, Gynecology \& Obstetrics and Anesthesiology, Biochemistry, PGIMS, India
}

Submission: December 03, 2017; Published: January 23, 2018

"Corresponding author: Parveen Malhotra, Department of Medical Gastroenterology, Gynecology \& Obstetrics and Anesthesiology, Biochemistry, PGIMS, 128/19, Civil Hospital Road, Rohtak, Haryana, India,Email: drparveenmalhotra@yahoo.com

\begin{abstract}
Introduction: The prevalence of chronic hepatitis $\mathrm{C}$ virus ( $\mathrm{HCV}$ ) infection has been estimated at between $1.2 \%$ and $1.7 \%$ in the adult global population whereas in India, the prevalence rate is estimated to be around 1\%. The main reasons for delay in developed countries is high cost and long waitlist but situation is totally reverse in developing country like India where total cost of treatment is exceptionally low and there is no waiting list.
\end{abstract}

Review of literature: HCV is a single-strand, positive-sense RNA virus and persons exposed to HCV have an estimated $75 \%$ to $85 \%$ likelihood of developing chronic infection, while the remainder experience spontaneous clearance of the virus. Of the chronically infected population, an estimated $5 \%$ to $20 \%$ develop cirrhosis over a prolonged period, often more than 20 years. Historically, HCV was treated with pegylated-interferon (PEG-IFN) alpha plus ribavirin (RBV) given for 24 weeks or 48 weeks. Following the approval of Directly acting antiviral medications, treatments that do not use Interferon became available for all HCV genotypes.

Summary and Conclusions: HCV treatment has focused on the costs of therapy in developed countries but in developing country like India, haryana state has developed a model named Jeevan rekha, whereby good policies has been made to omit acts of commission and purchasing through open transparent tender, thus passing benefit to needy patients.

Keywords: Chronic hepatitis c; Sofosbuvir; Ledipasavir; Daclastavir; Jeevan rekha

\section{Introduction}

The prevalence of chronic hepatitis C virus (HCV) infection has been estimated at between $1.2 \%$ and $1.7 \%$ in the adult global population, suggesting that 62 million to 89 million people are affected by the disease [1]. In India, the prevalence rate is estimated to be around $1 \%$. The past several years have seen a radical shift in how HCV is treated and in the number of patients who are successfully cured of the disease. The main reasons for delay in developed countries is high cost and long waitlist but situation is totally reverse in developing country like India where total cost of treatment is exceptionally low and there is no waiting list. These two maneuvers are key to curbing the menace of this deadly disease.

\section{Pathophysiology}

HCV is a single-strand, positive-sense RNA virus with a life cycle that begins when a viral capsid binds to the hepatocyte, where it undergoes endocytosis and once the new viruses are formed, they are packaged into envelopes to be released and further propagate the disease [2]. Acute HCV infections typically present with malaise, right upper quadrant pain, and nausea, similar in general to other acute viral hepatitis presentations. Patients are often not even aware of the acute infection, and many never seek treatment. Those exposed to HCV have an estimated $75 \%$ to $85 \%$ likelihood of developing chronic infection, while the remainder experience spontaneous clearance of the virus. Of the chronically infected population, an estimated $5 \%$ to $20 \%$ develop cirrhosis over a prolonged period, often more than 20 years. Those with cirrhosis face a $25 \%$ risk of progressing to end-stage liver disease (ESLD) or hepatocellular carcinoma (HCC). HCV is a diverse virus with at least seven well-characterized genotypes (GTs), defined as GTs 1-7, identified worldwide. These genotypes can differ by more than $50 \%$ in their nucleotide sequences, leading to varying responses to treatment strategies. In India, there is south west divide, highlighted by the fact that Genotype 3 is more prevalent in North India whereas Genotype 4 is more common in south. The recommended screening test is either an enzyme immuno assay or enhanced chemoluminescence immunoassay for antibodies to HCV (anti-HCV), and positive antibody test should be followed up with a qualitative or quantitative polymerase chain reaction test. 


\section{Treatment Overview}

Historically, HCV was treated with pegylated-interferon (PEG-IFN) alpha plus ribavirin (RBV) given for 24 weeks or 48 weeks. This combination produced average sustained virological response (SVR) rates of 50\%- 70\%, and was accompanied by a number of intolerable adverse effects, such as hemolytic anemia, flu-like symptoms, and psychiatric disturbances $[3,4]$. A treatment breakthrough came in 2011 with the approval of two oral DAAs, boceprevir and telaprevir. These agents were used in combination with PEG-IFN plus RBV for patients with GT 1 and increased SVR rates to as much as 70\%; however, these medications came with cumbersome dosing regimens, strict dietary requirements, and unfavorable adverse effect profiles [2]. A paradigm shift occurred in late 2013 with the approval of simeprevir and sofosbuvir within weeks of one another. These agents were the first oral once-daily treatments that were well tolerated and were able to produce SVR rates greater than 90\% either together in combination or with PEG-IFN plus RBV in select genotypes. Following the approval of additional DAA medications, treatments that do not use IFN became available for all HCV genotypes. Several well-tolerated, all-oral regimens are now approved to treat patients with various HCV genotypes, stages of liver disease, and comorbidities.

\section{Cost in past with pegylated interferon and ribavarin}

The oral antiviral drugs became available in India since 20th December, 2015 and before that Pegylated Interferon and Ribavarin was the only treatment available. In 2010, the cost of treatment for 24-48 weeks was 6650 Dollars-13300 Dollars for whole course of treatment. The Haryana government came up with the dedicated Jeevan rekha project for combating the menace of this disease and made Department of Medical Gastroenterology as Nodal Center and Dr. Parveen Malhotra as Principal Nodal officer of this project. Under this project patients belonging to below poverty line (BPL) and Schedule caste and tribes (SC/ST) were treated free and General category patients were treated at highly subsidized rate of 155-310 Dollars for whole course depending upon 24-48 weeks treatment. This maneuver lead to removal of acts of commission at various levels, thus made possible for many patients to come on treatment who were not able to afford treatment in past.

\section{Entry of oral antivirals in India}

The entry of oral antiviral in India since December, 2015 has become cornerstone of shift in paradigm of treatment of hepatitis $\mathrm{C}$. These directly acting oral antiviral have allay the fear of patients regarding lots of side effects which were there with Pegylated Interferon and Ribavarin. Moreover, the decreasing cost lead to increased affordability and coming on board for treatment by many needy patients.

\section{Sofosbuvir and ledipasvir}

The approval of the combination of ledipasvir $90 \mathrm{mg}$ and sofosbuvir 400mg (LVD/SOF), as a single-tablet formulation ushered in a new era for HCV treatment. Sofosbuvir is a potent pan genotypic NS5B, is a P-glycoprotein (P-gp) substrate, so caution should be taken with P-gp inducers, such as rifampin or St. John's wort. Sofosbuvir and its metabolites are renally eliminated, so its use is not recommended when a patient's creatinine clearance (CrCL) is less than $30 \mathrm{~mL} / \mathrm{min}$. The co administration of amiodarone and sofosbuvir-containing regimens following reports of serious symptomatic bradycardia and consequent deaths. Ledipasvir, which acts as a direct inhibitor on the active site of the NS5A protein, is available only in combination with sofosbuvir in the single-tablet regimen. This therapy is extremely well tolerated, with fatigue $(13 \%)$, headache $(14 \%)$, and nausea (7\%) being among the most common adverse effects in patients treated for 12 weeks. The use of LVD/SOF should be avoided in patients who are taking medications that suppress gastric acid, such as proton pump inhibitors (PPIs) or histamine-2 receptor antagonists (H2RAs), because this may reduce concentrations of LVD [5]. Genotype 1,4,5,6 daily regimen of LVD/SOF alone for 12 weeks is recommended in treatment-naïve patients with or without compensated cirrhosis whereas in decompensated cirrhosis, patients who have not failed an SOF-based regimen, a daily regimen of LVD/SOF plus initial low-dose RBV (600mg a day, then increased as tolerated) for 12 weeks is recommended. For patients who cannot tolerate or are otherwise ineligible for RBV, a daily regimen of $\mathrm{LVD} / \mathrm{SOF}$ for 24 weeks is also recommended [4].

\section{Sofosbuvir and daclastavir combination}

Daclatasvir $60 \mathrm{mg} /$ sofosbuvir $400 \mathrm{mg}$ for 12 weeks is a recommended regimen for GT 1,2 and GT 3 treatment-naïve noncirrhotic patients, but is considered an alternative with or without RBV in those with compensated cirrhosis for 24 weeks. For patients with decompensated cirrhosis or after transplant, DCV/SOF may be considered in GT 1-4 with RBV for 12 weeks or for 24 weeks without RBV if ineligible [4,6]. Eradication of HCV has been shown to reduce the number of patients who develop type-2 diabetes as well as reduce cardiovascular-and renalrelated outcomes in patients who are already diagnosed with diabetes $[7,8]$.

\section{Role of haryana government in India}

The Haryana government under Jeevan rekha project is giving totally free treatment including diagnostic tests like HCV RNA Quantitative \& Genotype, Fibroscan, Endoscopy, and all other routine tests like Liver function tests, Renal function tests etc, to every resident of haryana who is suffering from hepatitis $\mathrm{C}$. The haryana government bears a burden of 140 Dollars/ patient for whole course of treatment for 12 weeks and provides totally free treatment to residents of haryana. The patients belonging to states other than haryana are being treated at minimal rate of 260 Dollars for whole course including all the tests. The Punjab state also provides free oral antiviral drugs but the patient has to pay for diagnostic tests which amount to 155 Dollars for 
whole course. The present cost of treatment in United States of America for 12 weeks treatment is 84000 Dollars in comparison to just 260 Dollars in haryana which even includes the cost of diagnostics whereas there is additional cost for these tests in abroad countries, which puts extra burden on the patient.

Hence, haryana has the distinction of only place in the world where it is providing free treatment to its residents and world's lowest price to others. Hence many patients belonging to neighboring states like Uttar Pradesh, Uttarakhand, New Delhi, Punjab and even abroad countries come for treatment. Thus a good policy not only impacts the native state but surrounding geographical areas also. Uptill now around ten thousand patients have been treated under this project, including both free group and subsidized and results are excellent with SVR of more than $96 \%$, mainly due to predominantly non-cirrhotic group, good compliance, less side effects, easy accessibility \& affordability, no waiting list.

\section{Summary and Conclusion}

Much of the discussion about HCV treatment has focused on the costs of therapy given the large up-front prices in developed countries but in developing country like India, haryana state has developed a model named Jeevan rekha, whereby good policies has been made to omit acts of commission and purchasing through open transparent tender, thus passing benefit to needy patients. Hence, haryana has the distinction of only place in the world where it is providing free treatment to its residents and world's lowest price to others. Hence many patients belonging to neighboring states like Uttar Pradesh, Uttarakhand, New Delhi, Punjab and even abroad countries come for treatment.

\section{References}

1. Gower E, Estes C, Blach S, Razavi-Shearer K, Razavi H (2014) Global epidemiology and genotype distribution of the hepatitis $C$ virus infection. J Hepatol 61(1 suppl): S45-S57.

2. Ray SC, Thomas DL, Hepatitis C (2015) Mandell, Douglas, and Bennett's Principles and Practice of Infectious Diseases. In: Bennett JE, Dolin R, Blaser MJ (Eds.), Mandell, Douglas, and Bennett's Principles and Practice of Infectious Diseases. ( $8^{\text {th }}$ edn), Philadelphia, Saunders, Pennsylvania, USA, pp. 1904-1927.

3. Messina JP, Humphreys I, Flaxman A, Brown A, Cooke GS, et al. (2015) Global distribution and prevalence of hepatitis $C$ virus genotypes. Hepatology 61(1): 77-87.

4. American Association for the Study of Liver Diseases/ Infectious Diseases Society of America (2016) Recommendations for testing, managing, and treating hepatitis $\mathrm{C}$.

5. (2017) Harvoni (sofosbuvir/ledipasvir) prescribing information. Forest City, Gilead Sciences, California, USA.

6. (2016) Daklinza (daclatasvir) prescribing information. Princeton, Bristol-Myers Squibb, New Jersey, USA.

7. Arase Y, Suzuki F, Suzuki Y (2009) Sustained virological response reduces incidence of onset of type-2 diabetes in chronic hepatitis C. Hepatology 49(3): 739-744.

8. Hsu YC, Lin JT, Ho HJ, Kao YH, Huang YT, (2014) Antiviral treatment for hepatitis $\mathrm{C}$ virus infection is associated with improved renal and cardiovascular outcomes in diabetic patients. Hepatology 59(4): 12931302.

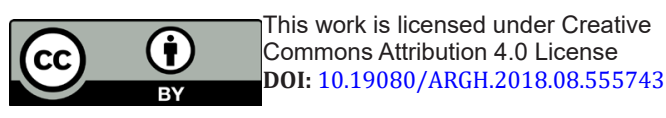

Your next submission with JuniperPublishers
will reach you the below assets
- Quality Editorial service
- Swift Peer Review
- Reprints availability
- E-prints Service
- Manuscript Podcast for convenient understanding
- Global attainment for your research
- Manuscript accessibility in different formats
( Pdf, E-pub, Full Text, audio)
- Unceasing customer service
Track the below URL for one-step submission
https://juniperpublishers.com/online-submission.php

